\title{
Regional tectono-sedimentary development of the highs and basins of the northwestern Barents Shelf
}

\author{
Ingrid Anell', Jan-Inge Faleide' \& Alvar Braathen'
}

${ }^{1}$ Department of Geosciences, Sem Seelands Vei 1, 0371 Oslo.

E-mail corresponding author (Ingrid Anell): Ingrid.anell@gmail.com

While many structural elements on the northwestern Barents Shelf initiated early and have remained influential on accommodation and sedimentation, detailed seismic interpretation attests to the development of new structural elements, shifting locus of influence, and burial, reactivation and inactivation at different times of various highs and basins. NE-SW-oriented structural elements such as the Gardarbanken and Hopen highs, and the Capria ridge (informally named herein), have old Carboniferous foundations and show signs of reactivation in the Early Triassic. Towards the southwest, the Capria ridge merges with the paleo-Stappen high, which is a N-S, tilted peneplaned, Late Carboniferous rift-shoulder which deeply erodes the Carboniferous deposits, and is onlapped by Permian and Early Triassic sediments. The paleosurface is overprinted by the dominantly post-Cretaceous development of the Stappen High, which has a maximum uplift and extent south of Bjørnøya. The Sørkapp basin is the main depocentre on the northwestern Barents Shelf; however, the Storjorden, Edgeøya and Ora (informally named herein) basins all formed around the same time in the Carboniferous. While the Sørkapp basin remained a sag basin until the Ladinian, the Edgeøya basin, a narrow rift basin, became largely inactive following infill. As a result, the Hopen high and Edgeøya platform, which bounded the Edgeøya basin, merged to form the Svalbard platform. The Storfjorden basin was reactivated around the Mid Jurassic when the Sørkapp depression, forming west of the Sørkapp basin, was initiated. Both basins are asymmetrical and bounded by gentle anticlinal features on one side implying formation associated with contraction. Cretaceous sediments, largely eroded from the area, are found in basins such as the Olga basin, which formed between two anticlines. One of these anticlines is the Sentralbanken high, which contrary to most other highs in the area shows no signs of initiation in the Carboniferous, but rather appears to have been a depocentre which was inverted around the Cretaceous.

Keywords: Barents Shelf, structure, sedimentation, Palaeozoic, Mesozoic

Received 5. November 2015 / Accepted 22. January 2016 / Published online 1. March 2016

\section{Introduction}

The shallow northwestern Barents Shelf has undergone multiple changes in stress regimes and continental collision, periodic rifting, uplift, large-scale subsidence, tilting and folding have contributed to the present configuration of emergent land areas, highs, basins and platforms (Fig. 1A). Reflecting the prolonged history, the tectonic style, timing and causal mechanisms behind the development on the northwestern Barents Shelf remains poorly understood. This is largely due to limited and low data quality, but also to difficulties in resolving individual stages or mechanisms in a polyphase setting. Further confounding the situation is a still partly unstructured nomenclature which includes the same names used for different structures, unnamed and unidentified features, and single names for older and younger, partly overprinted features with different developments.

It is apparent that the development of the northwestern Barents Shelf reflects shifting stress regimes and shifting locus of influence (Rønnevik \& Jacobsen, 1984; Riis et al., 1986; Wood et al., 1989; Faleide et al., 1993, 2008; Braathen et al., 1999b; Grogan et al., 1999; Worsley et

Anell, I., Faleide, J.-I. \& Braathen, A. 2015: Regional tectono-sedimentary development of the highs and basins of the northwestern Barents Shelf. Norwegian Journal of Geology 96, 27-41. http://dx.doi.org/10.17850/njg96-1-04. 

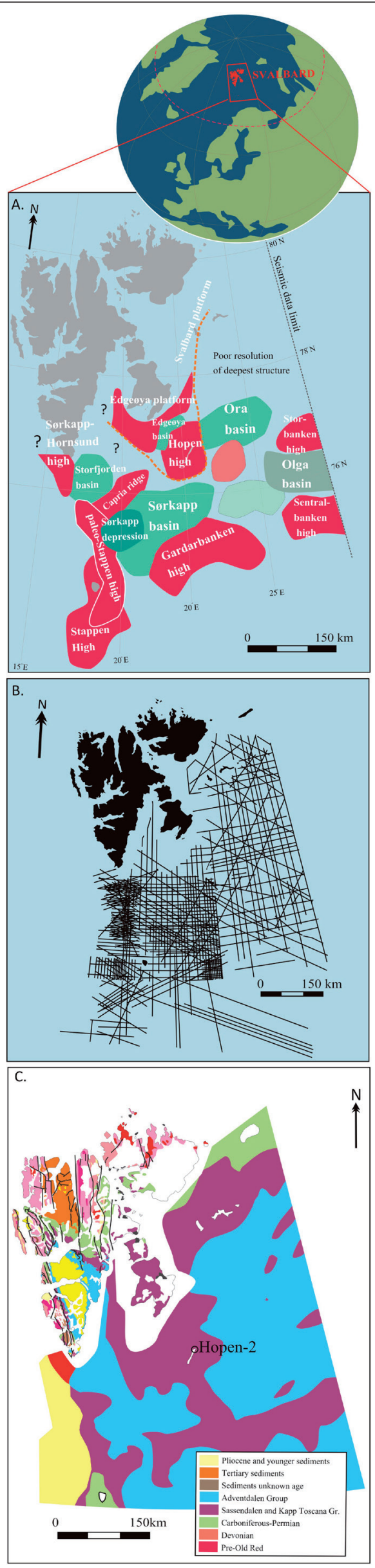

al., 2001; Worsley, 2008; Barrère et al., 2009; Ritzmann \& Faleide, 2009; Henriksen et al., 2011; Gac et al., 2012; Gernigon et al., 2014). It has previously been observed, for example, that the Sørkapp basin, which forms the main Carboniferous depocentre on the northwestern Barents Shelf (Fig. 2A), remained a sag between highs until the Late Triassic, when a new depocentre, the Sørkapp depression, developed towards the west (Anell et al., 2014a). The Stappen High, the Sørkapp basin's western border, lies on the boundary between the Barents Shelf and the spreading North Atlantic. Its present structural configuration is the result of postCretaceous uplift and it partly overprints a high with a similar orientation but different structural development which formed in the Late Carboniferous. Previously, the Stappen High has been defined at an Upper Permian level, with the name also used to discuss the earlier Palaeozoic development (Gabrielsen et al., 1990). However, this study observes significant differences and a need to differentiate between two features; the Stappen High and paleo-Stappen high. The older of the two, the paleo-Stappen high, itself partly overprints a previously unidentified NE-SW-oriented high which forms the northwestern border of the Sørkapp basin. In line with the naming of structural features from Norwegian polar vessels, we tentatively refer to this high as the Capria ridge, after the 1917 ship $\mathrm{P} / \mathrm{R}$ Capria which sank in 1927. The Capria ridge is oriented NE-SW in line with the Gardarbanken high and the Edgeøya basin, while the paleo-Stappen high is oriented $\mathrm{N}-\mathrm{S}$ in line with the structural grain of the main fault lineations on Svalbard such as the Billefjorden Fault Zone and the Lomfjorden Fault Zone (Braathen et al., 1999b; Bælum \& Braathen, 2012). The Capria ridge may provide key insight into the development of the northwestern Barents Shelf in relation to orientation of the structural elements as it lies right on the transition from dominantly $\mathrm{N}$-S-oriented structures near the margin to a NE-SW orientation eastward on the shelf.

How, when and where the various highs and basins within the study area, roughly defined by the seismic data coverage (Fig. 1B), were formed, and when and if they reactivated is the main focus of this paper. The locus and timing of the activity of the structural features can provide insight on the deep structural grain, the far-field stresses in relation to orogenic development and rifting, and a better understanding of sediment deposition, condensation and erosion in the area.

Figure 1. (A) The main structural elements of the northwestern Barents Sea based on this study. (B) Location of the seismic lines used in this study which outline the main study area. (C) The present geological subcrop pattern from onshore Svalbard (adapted from Dallmann et al., 2002) with the offshore geology based on interpretation in this study with minor guidance based on Sigmond (1992). The location of the Hopen-2 well, mentioned in the text, is marked. 


\section{Geological background}

The Barents Shelf is a shallow platform comprising a series of sub-platforms, highs and basins (Fig. 1A) (Rønnevik et al., 1982; Gabrielsen et al., 1990; Faleide et al., 1991, 2008; Gudlaugsson et al., 1998; Grogan et al., 1999; Worsley et al., 2001; Henriksen et al., 2011). The orientation of lineaments reflects the inherited structural grain from the Late Neoproterozoic Timanian orogeny (Roberts \& Siedlecka, 2002; Siedlecka et al., 2004) and two ensuing major orogenic events; the Silurian-Devonian Caledonian (Scandian) orogeny and Ellesmerian orogeny (Gee, 1975; Soper \& Higgins, 1990; Higgins et al., 2000; McKerrow et al., 2000; Gee \& Teben'kov, 2004; Johansson et al., 2005; Labrousse et al., 2008; Gernigon et al., 2014), and towards the east the Carboniferous-Triassic Uralian orogeny (Otto \& Bailey, 1995; Berzin et al., 1996; Witt-Nilsson et al., 1998; Gee et al., 2006). The Caledonian orogenic welt in the northern Barents Shelf remains enigmatic in the constellation (Gernigon \& Brönner, 2012), but was inherently unstable, and likely experienced late/post-orogenic collapse (Doré et al., 1999; Braathen et al., 2010; Leever et al., 2011). Though poorly visualised on the Barents Shelf, there may be deep basins comprising Devonian molasse, similar to those in the Scandinavian Caledonides (Andersen, 1998; Braathen et al., 2002). A rift phase occurred in the Mid Carboniferous throughout the Barents Shelf creating many interconnected extensional basins separated by highs, which were infilled and blanketed during the latest Carboniferous-Permian (Dengo \& Røssland, 1992; Gudlaugsson et al., 1998; Faleide et al., 2010). The deposits generally comprise continental alluvial deposits, interfingering with evaporates and carbonates, transitioning to fluvio-deltaic and shallow-marine platform deposits towards the end of the Carboniferous (Steel \& Worsley, 1984; Nøttvedt et al., 1992b; Worsley et al., 2001; Braathen et al., 2011). Large-scale movements in the eastern areas of the shelf generally ceased following the Carboniferous and the shelf developed as a large interior sag basin (Dengo \& Røssland, 1992; Gudlaugsson et al., 1998). However, a rifting phase along the western margin affected $\mathrm{N}-\mathrm{S}$ lineaments such as the Loppa, 'Stappen' and Sørkapp-Hornsund highs in the Permo-Triassic (Faleide et al., 2010). During the Triassic the Barents Shelf was flooded and the previous dominantly carbonate platform was infilled with siliciclastic material derived mainly from the Urals and

Figure 2. (A) Map of TWT (two-way-travel time) to an Early Carboniferous reflector, which shows most of the main early structural elements. The exact age of the reflector remains uncertain. (B) Isopach of the Early Carboniferous through Permian deposits. (C) TWT to the Base Triassic reflector which shows the thickness of the Mesozoic succession to the sea floor, parts of which have been eroded. All maps were made in Petrel under academic license agreement.

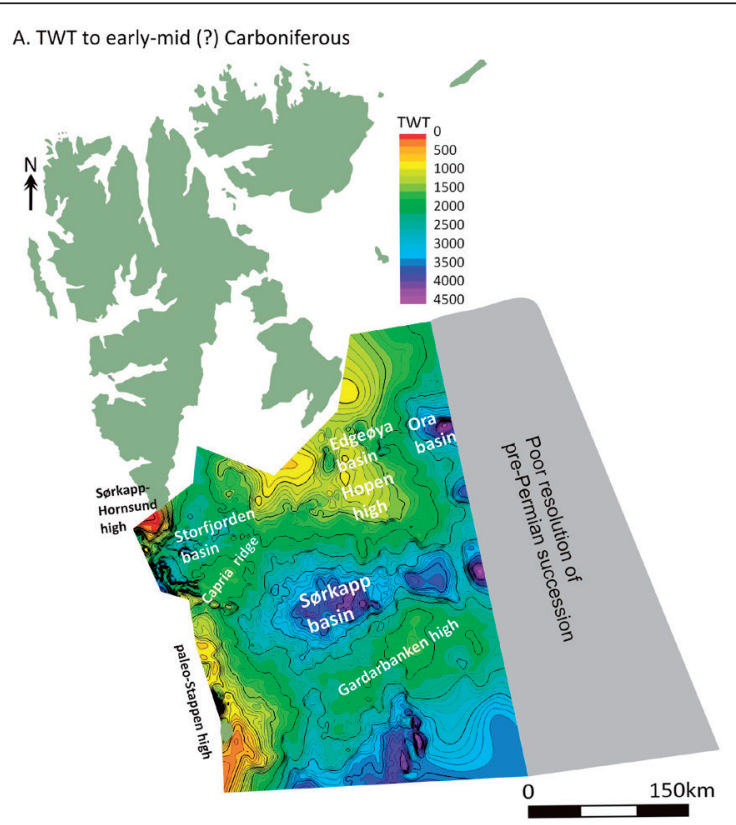

B. Thickness of Carboniferous - Permian (in TWT)

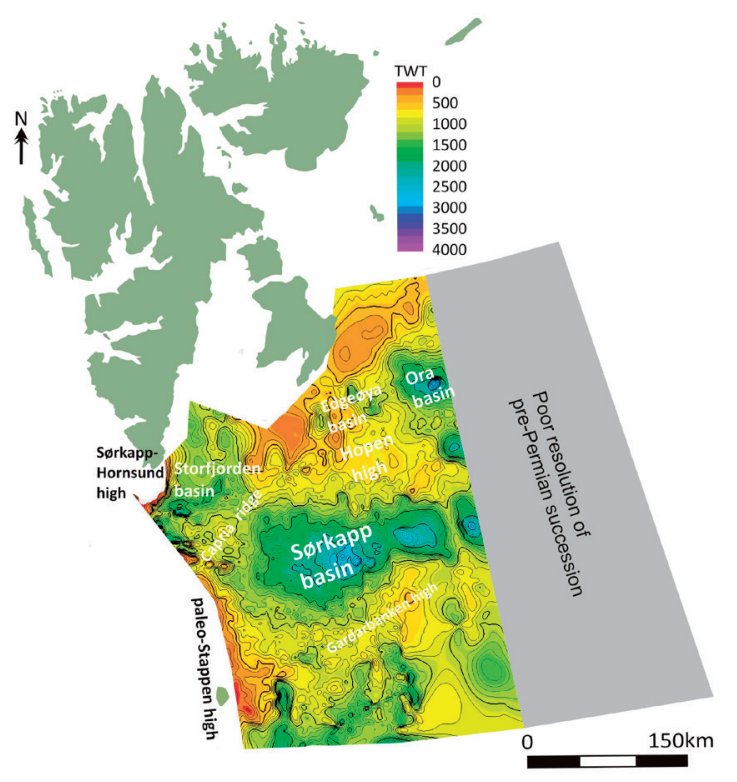

C. TWT to base Triassic

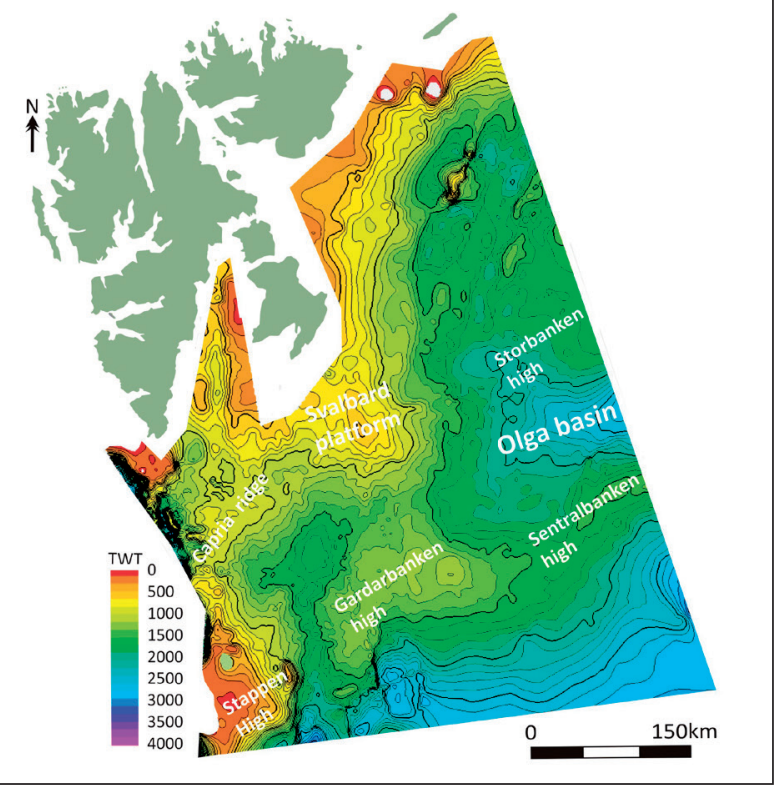


the Baltic Shield (Bue et al., 2010; Glørstad-Clark et al., 2011; Anell et al., 2014b). In the Early Triassic, however, a prominent western source prevailed around the presently exposed island of Spitsbergen (Mørk et al., 1982; Nøttvedt et al., 1992a; Bue et al., 2010; Bue, 2012) which is not apparent in the Late Triassic (Anell et al., 2014b). The Gardarbanken high has been proposed to have hindered Early Triassic platform-edge advance towards the northwest (Anell et al., 2014c), and other features may similarly have influenced depositional patterns during the various stages of infill.

\section{Database}

The results of the study are based on $2 \mathrm{D}$ seismic interpretation of an extensive dataset covering the northwestern Barents Shelf (Fig. 1B). The age of reflectors is based on previous work done in the Sørkapp basin (Anell et al., 2014a) which uses the Hopen-2 well (Fig. 1C) along with dating of shallow cores (Riis et al., 2008) to establish the ages of the reflectors.

The seismic lines used in the study were acquired from 1974 and onwards and made available by the Norwegian Petroleum Directorate (NPD). Typical spacing is between 5 and $10 \mathrm{~km}$ (Fig. 1B). The data quality is relatively poor, resulting from the impact of shallow water and the hard sea floor, high interval velocities in subcrop below a thin Quaternary cover, and/or shallow volcanic intrusions and extrusions (Grogan et al., 1999). Resolution and interference of multiples becomes particularly prominent beneath structural highs and over condensed platform deposits, whereas acceptable resolution down to 3-4 seconds is usually available in the depocentres, although some of the deep and narrow rift basins bounded by steep-sided faults are still difficult to distinguish.

\section{Results}

We discuss the development of the northwestern Barents Shelf based on seismic interpretation which allows us to describe the outline, characteristics and timing of formation and reactivation of the main structural elements. Although there are limitations and uncertainties as a result of the relatively poor data quality and limited well coverage, there are many observations which provide interesting links to understanding the area's fundamental development.

Many of the structural features are outlined by deep reflective elements and have generally remained influential as either highs or basins since their initiation. The onset of formation of these earliest structural elements is difficult to pinpoint, but the dominant phase of formation is likely to be around the Carboniferous.
Since the deepest traceable reflectors are generally poorly resolved, hard to separate and correlate, many highs which initiated at an early stage are easiest to map via reactivational surfaces. Reactivation occurred via significant faulting, discrete small-scale movements, broad down-warping or flexuring. While the latest Palaeozoic and Mesozoic time intervals were dominated by sub-parallel platform deposition (Grogan et al., 1999), reactivation, inactivation and shift of the main locus of influence has occurred, which indicates changes in the stress regime across the shelf.

\section{Structural elements}

\section{Structural highs}

The Stappen High, paleo-Stappen high and Capria ridge (Figs. 3, 4, 5) are three separate features which partly overlap and whose development has often been discussed as that of a single structure. Initiation of the Stappen High's present configuration (Faleide \& Gudlaugsson, 1981; Faleide et al., 1984; Gabrielsen, 1984) is still poorly constrained, though it is chiefly a Cretaceous and Cenozoic feature (Gabrielsen et al., 1990; Worsley et al., 2001). The Stappen High is bounded to the west by the Knølegga Fault Zone, which comprises several overall $\mathrm{N}-\mathrm{S}$-oriented faults with large offsets (C-C', Figs. 3, 4). To the south and southeast the High is bounded by the Bjørnøya Basin. The southeastern boundary is drawn herein at the subcrop of the base Cretaceous reflector, which forms a NE-SW-oriented boundary (Fig. 1A). Towards the east the high is bounded by the Sørkapp depression and the Hopenbanken arch (Halland et al., 2014) which forms a relatively gentle saddle comprising $\mathrm{N}$-S-oriented anticlines between which narrow Cretaceous deposits are preserved, and which separates the Stappen High from the Gardarbanken high (Fig. 2C). Towards the north, a complex series of in places poorly visualised faults separate it from the Sørkapp-Hornsund high (Fig. 1A). Maximum uplift and greatest lateral extent of the Stappen High occurs in the south, with a gentle, narrowing, low-angle flank dipping towards the north characterising the northern part. Basement rocks and Palaeozoic sediments subcrop along the axis which exposes Bjørnøya, the only subaerially exposed part of the High (E-E), Fig. 5) (Steel \& Worsley, 1984; Gabrielsen et al., 1990; Braathen et al., 1999b; Grogan et al., 1999; Worsley et al., 2001).

The paleo-Stappen high is traced via a Late Carboniferous truncation and erosion surface which forms a planation surface and has a distinct tilted flank along its eastern edge (C-C', D-D', Fig. 4). Along the resolvable length the planation surface is at present generally at a depth of around 1-2 seconds (c. 2-4 km) (Figs. 2, 4). The high is oriented N-S with maximum uplift and erosion north of Bjørnøya. The planation surface deeply 

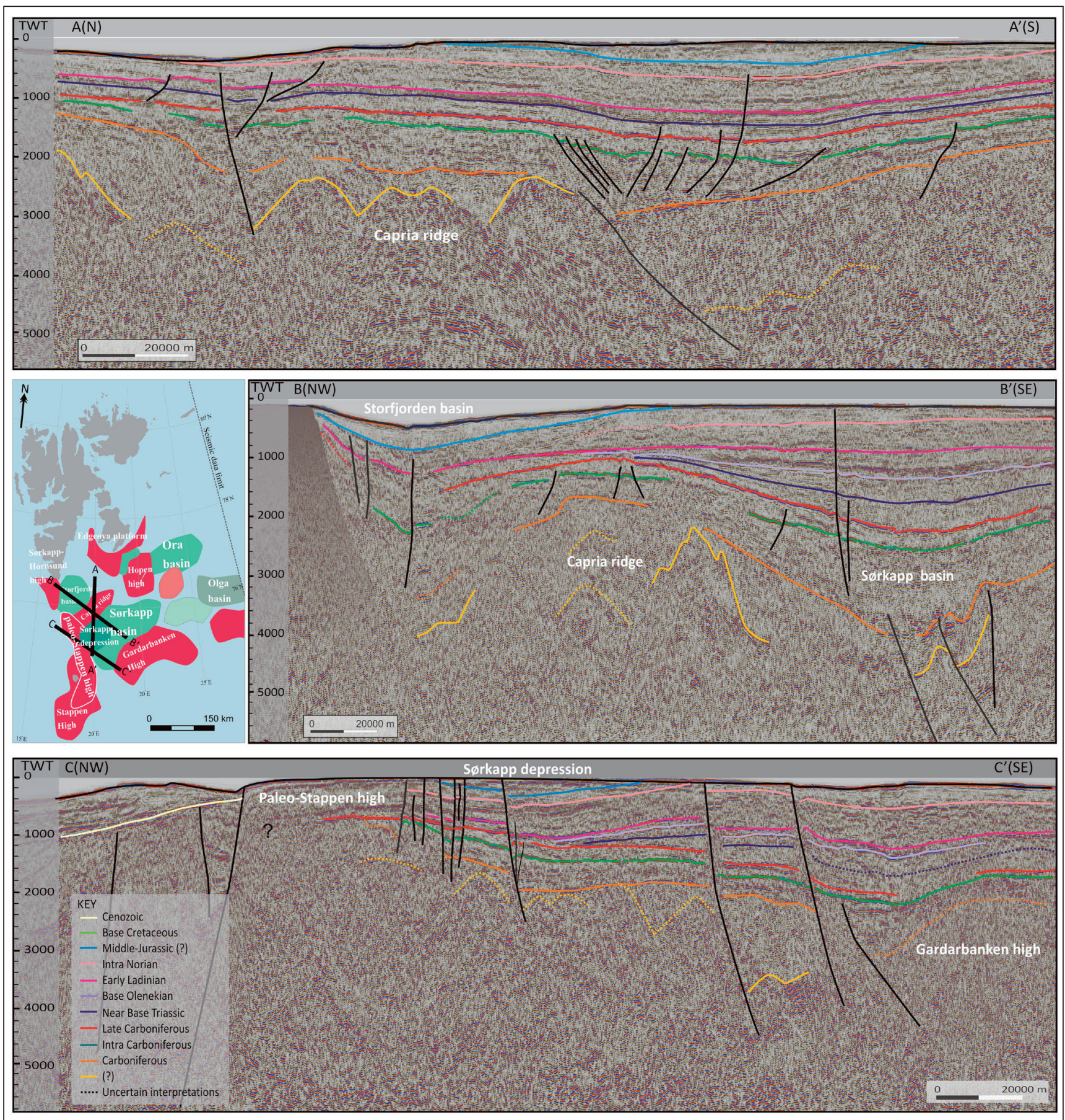

Figure 3. $2 D$ seismic transects showing several of the structural elements in this study. The map shows the location of the transects and orientation is given at the top of each line.

erodes the underlying Carboniferous succession and is progressively onlapped by Permian and Early Triassic deposits from the east, and transgressed completely in the Ladinian (C-C, D-D, Fig. 4). The surface is difficult to follow westward due to resolution, faulting along the Atlantic margin and the recent uplift of the Stappen High. The boundary is at present drawn along a westward-facing fault outlining a sub-basin of unknown age, which separates the paleo-high from a second deep structure which forms the subcrop of Bjørnøya (E-E,
Fig. 5). Towards the south the high deepens beneath the Bjørnøya Basin and towards the north there is less distinct truncation and erosion, and the planation surface is recognised only via onlap of Permian and Early Triassic deposits onto the tilted flank (D-D, Fig. 4). Still farther north, only minor Permian thinning is observed and the development of the high is overprinted by reactivation of the Capria ridge in the Early Triassic and development of the Sørkapp depression and the Storfjorden basins around the Mid Jurassic. 
The Capria ridge is a NE-SW-oriented structure which at present forms a shallow ridge with Triassic subcrop bounding two depocentres of the Adventdalen Group (Fig. 1C). The Capria ridge can generally be visualised on seismic as a domal or a series of domal reflectors which occur at a depth of around 3 seconds (c. 6-7 km) (A-A', B-B', Figs. 3, 4). The undulating and, in places, high impedance contrast reflectors likely represent low-angle, rotated, deeply eroded, Carboniferous fault-blocks. The significant rotation of the blocks suggests an underlying, low-angle, supra-detachment fault system. Thick deposits accumulated on both sides of the high during the Carboniferous (A-A, B-B', Figs. 2B, 4). The high is best traced via an intra-Carboniferous reflector, which drapes the topography and truncates reflectors across the high forming a planation surface, with continued thicker infill on either side (A-A', Fig. 4). The paleo-Stappen high's configuration partly overlaps the southwestern part of the Capria ridge, making it difficult to determine its original extent and the relationship between the two highs (B-B', Figs. 2A, B, 4). The western boundary of the Capria ridge has been segmented by fault activity along the Knølegga Fault Zone (Fig. 6B) which developed in conjunction with continental separation. This means that the northeastern segment can be visualised in its entirety while the original extent of the southwestern segment is challenging to map. The high was reactivated via flexuring in the Early Triassic with maximum influence in the southwest. The high's southwestern edge appears to have been at or near subaerial exposure with indications of complex intermittent erosion and deposition during the Late Carboniferous through Early Triassic (B-B', Fig. 4). Thinning of the Early Triassic succession diminishes towards the northeast (A-A', Fig. 4). The high's northeastern limit is set where influence on Triassic sedimentation becomes negligible.

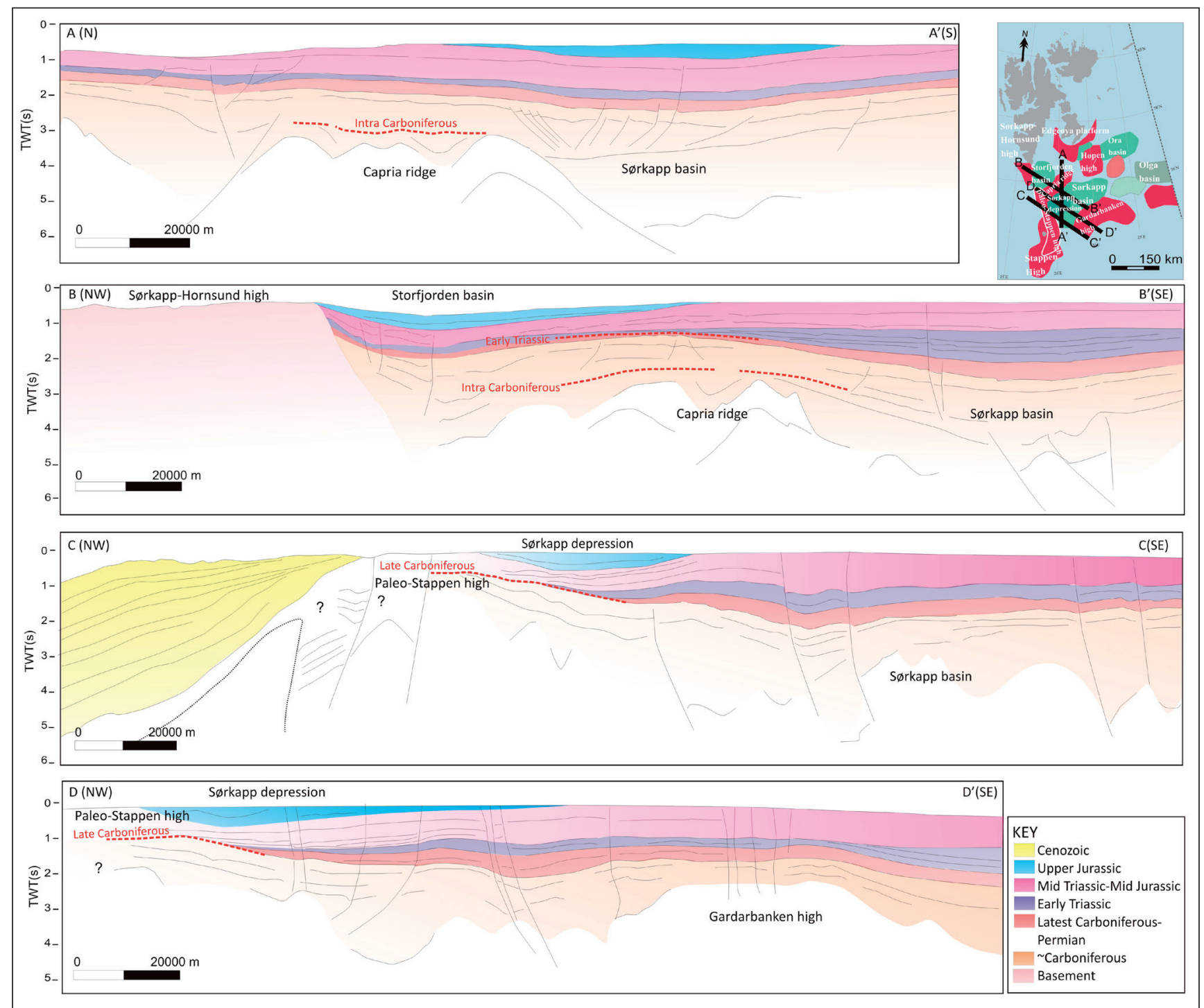

Figure 4. Interpreted transects of seismic sections across several of the main structural elements discussed in this study. Lines A-C correspond to the seismic lines from Fig. 2. The map in the upper right corner shows the location of the lines, the box in the lower right corner shows the approximate ages of the various units. 

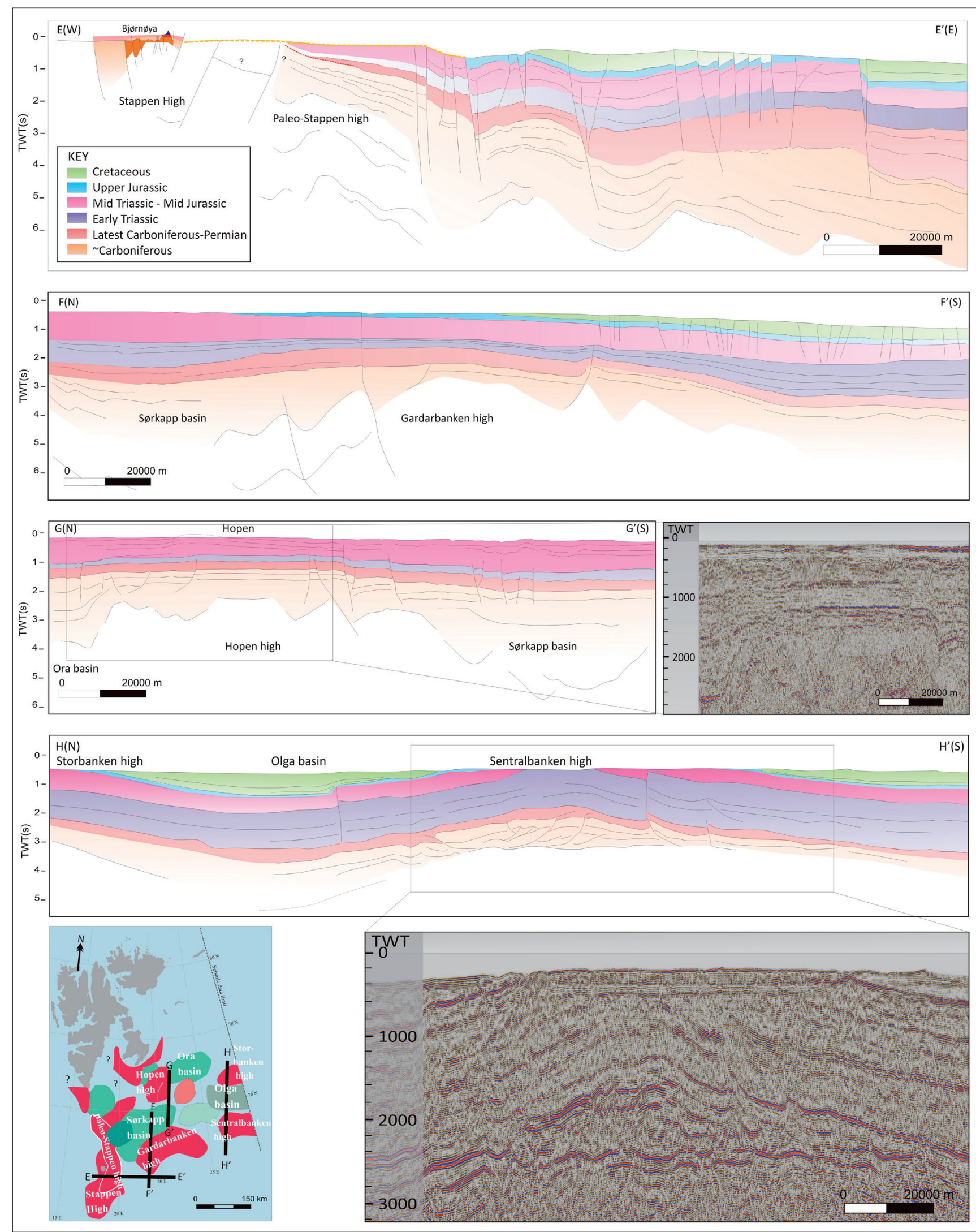

Figure 5. Interpreted transects of seismic sections across the study area showing some of the main structural features with examples of the seismic data for line G-G' and line H-H'. The locations of the lines are marked on the map. The outcrop of Bjørnøya along line E-E' is based on Worsley et al. (2001).

The Gardarbanken high (Gabrielsen et al., 1990) is a prominent structure at depth which formed at the onset of rifting in the Carboniferous (Fig. 2A). The high forms an elongated domed to flat-topped shape (D-D', 
Fig. 4), oriented roughly NE-SW and bounded by a complex pattern of faults. The high itself is largely free of reflections and is traceable mainly through the reflective depocentres on either side. Throughout the Late Palaeozoic the high formed part of a shallow ridge, with a domal-shaped high-point in the northeast (Fig. 2B). The Late Carboniferous/Permian succession is largely unaffected across the Gardarbanken high although minor growth on down-to-SE faults is recorded in the Late Carboniferous. The high was reactivated in the latest Permian-Early Triassic with dominant influence seen on the southeast flank where the Early Triassic onlaps, thins and in places is truncated and eroded, suggesting partial subaerial erosion (D-D', Fig. 4; F-F, Fig. 5). There is no appreciable fault activity in conjunction with this phase of reactivation suggesting it was dominantly a flexural upwarp. The truncation and erosion of the post Mid Jurassic to Late Cretaceous Adventdalen Group across the high suggests that reactivation also occurred at a later stage. This phase is represented predominantly by large-scale down-to-south faulting onto the Bjarmeland Platform, with thick Cretaceous accumulations preserved, which suggests that, like in the Early Triassic, southfacing lineaments reactivated to a greater extent than the faults on the northwestern side (F-F', Fig. 5).

The structural features of the area around Svalbard and Hopen are commonly discussed using the names Edgeøya platform (Bergsager, 1986; Gabrielsen et al., 1990; Doré, 1995) and Svalbard platform interchangeably (Skilbrei, 1991; Nøttvedt et al., 1992a; Gudlaugsson et al., 1998; Grogan et al., 1999; Worsley et al., 2001; Henriksen et al., 2011). This is likely due to the existence of the poorly visualised Edgeøya basin (Elverhøi et al., 1988; Doré, 1995), which separates the Edgeøya platform from the Hopen high (Fig. 2A, B). Incidentally, the term 'Hopen high' is sometimes used to name the northern anticline bounding the Olga basin (Doré, 1992; Henriksen et al., 2011) as well as the high around the island of Hopen (Elverhøi et al., 1988), which was originally thought to be a larger structure extending farther north (Gabrielsen et al., 1984; Rønnevik \& Jacobsen, 1984; Riis et al., 1986). Given that the island of Hopen sits on a high, in this study we refer to that structure as the Hopen high and the anticline bordering the Olga basin as the Storbanken high (Antonsen et al., 1991), Storbanken being the name given to the shallow bank, or bathymetric high, overlying the anticline (Solheim \& Elverhøi, 1993; Falk-Petersen et al., 2000; Andreassen et al., 2008).

Following cessation of activity in the Edgeøya basin, which probably occurred in the Late Carboniferous, it appears as if the development of the Edgeøya platform and the Hopen high was largely co-dependent and that the two highs merged to become a single element which is herein referred to as the Svalbard platform. However, minor differential subsidence across the Edgeøya basin attests to a certain degree of independence from the Hopen high (Fig. 2C). On many profiles the Hopen high is not well resolved and traced via its overall sub-domal shape which outlines a roughly triangular-shaped feature (G-G', Figs. 2A, 5). The best visualised faults bounding the Hopen high are oriented E-W along the southern side of the high; these show significant offset around the Mid Carboniferous and also growth in the Late Carboniferous, and again in the Early Triassic (G-G', Fig.

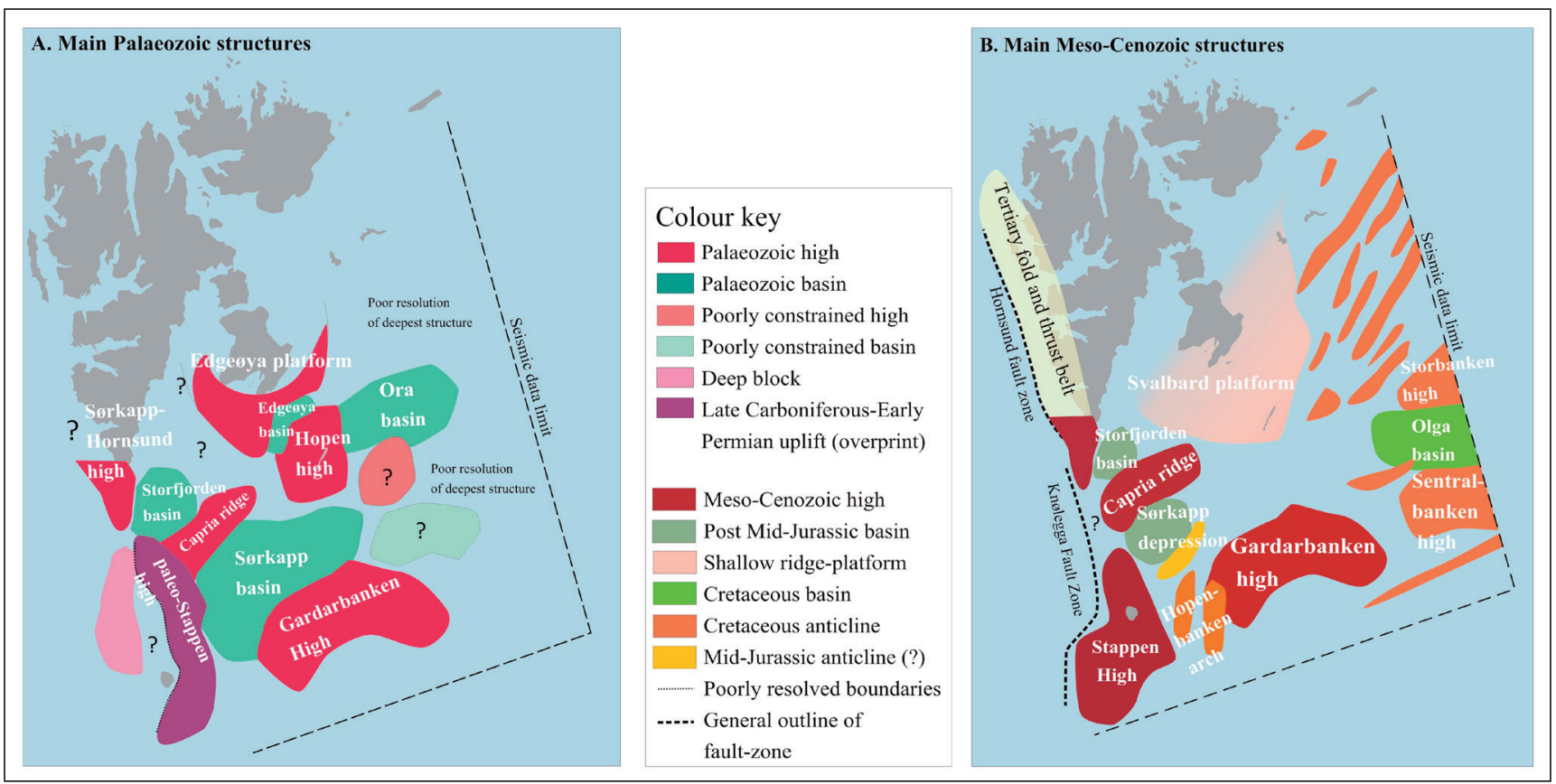

Figure 6. (A) A simplified paleogeographic image of the locations of highs and basins upon early initiation around the Carboniferous, with the paleo-Stappen high, uplifted in the Late Carboniferous, marked in purple, although it may also have been active before this. Structures with poorly resolved boundaries are stippled. (B) The development of structural features from the Triassic onward. 
5). The high is bounded by basins to the northeast and northwest and most likely by a gentle undulating slope toward the east which may encompass a deeper poorly resolved high (Figs. 1A, 2B). The Edgeøya platform (and consequently large parts of the Svalbard platform) is difficult to discuss as most of the area is not covered by the available seismic data. Furthermore, the exact separation between the Edgeøya platform and the Capria ridge is difficult to define at depth due to the limited coverage of seismic lines in this region.

The Sentralbanken high (Rønnevik et al., 1982) is only partly covered by the seismic data (Fig. 1A). Together with the similarly oriented Storbanken high towards the north, it forms the borders of the Olga basin (H-H', Fig. 5; Gabrielsen et al., 1990). The Sentralbanken high has been proposed to have become emergent already in the Carnian (Doré, 1992). However, the main phase of uplift and erosion appears to be contractional doming which was probably initiated around the Early Cretaceous given the onlap pattern above the base Cretaceous reflector (H-H', Fig. 5). It is, however, difficult to rule out activity in the Mid to Late Jurassic, as these deposits appear thin and provide limited information. The Sentralbanken high forms the largest of several anticlines which developed in the eastern part of the study area (Fig. 6B). Most are narrow, oriented NE-SW and have steeper sides facing northwest. The island of Hopen, on the Hopen high, shows a similar orientation to the anticlines, and the seismic data show evidence of development of a small anticline, which appears far less prominent than those farther northeast (G-G', Fig. 5). It is inferred that the outcrop of the island could be the result of formation of a narrow anticline (F-F, Fig. 5). The Sentralbanken high has a uniformly thick Permo-Triassic succession showing no marked structural activity during this period; and it is underlain by a relatively thick Carboniferous succession suggesting that it initiated as a fault-bound depocentre. The contractional deformation is best seen in the Permo-Carboniferous succession where reverse faults accommodated the movement, while most of the Triassic succession forms a relatively unfaulted dome above. However, at least one major reverse fault on the southern edge of the high penetrates through the entire preserved succession (H-H', Fig. 5), attesting to a postJurassic inversion event.

\section{Basins}

The Sørkapp basin (Rønnevik et al., 1982; Elverhøi et al., 1988) forms one of the largest depocentres on the northwestern Barents Shelf, bordered by highs on all sides (Fig. 2A). It is a NE-SW to E-W-oriented elongate basin with a relatively symmetric geometry (F-F, G-G', Fig. 5). The main basin-forming stage and fill is Carboniferous in age. The deepest part is hard to distinguish but the largely unfaulted post-rift sag-fill, is $>2$ seconds (c. $4 \mathrm{~km}$ ) thick at its maximum (G-G', Fig. 5). At latest Carboniferous through Early Mesozoic levels it forms a gentle syncline, periodically with minor thickening across the basin compared to surrounding highs (Fig. 4). Following the Ladinian flooding, there is no thickness variation observed across the Sørkapp basin and instead deposition shifts to the Sørkapp depression (Anell et al., 2014a) which lies west of the basin and forms a post Mid Jurassic depocentre (C-C', Fig. 4). Initiation of the Sørkapp depression may be associated with the formation of a gentle anticline in the western part of the Sørkapp basin, where the Permian to Mid Jurassic succession forms an upwarp bounding the eastern edge of the depression (C-C', D-D', Figs. 4, 6B).

The Storfjorden basin is a similar-sized and similar age basin to the Sørkapp depression which formed over a deeper, poorly visualised, Carboniferous basin (B-B', Figs. 2B, 4). Its development is controlled dominantly by movement on a dip-slip, down-to-east fault along the southeast margin of the Sørkapp-Hornsund high, with the Capria ridge and the Svalbard platform acting as boundaries to the northeast and the south. Both the Storfjorden basin and the Sørkapp depression are rounded depocentres, internally asymmetric with steeper sides to the west. Their western boundaries appear fault controlled while gentler anticlinal features bound them towards the east, although the Storfjorden basin has only limited seismic data coverage and is partly overprinted by the Tertiary fold-and-thrust belt (Fig. 6B).

The Edgeøya basin is a small but deep poorly resolved basin oriented NE-SW, which formed between the Hopen high and the Edgeøya platform (Fig. 2A, B). It forms a narrow fault-bounded depocentre, with c. 1.5 seconds $($ c. $3 \mathrm{~km})$ of rift fill. It appears to have been largely inactive following rifting and infill during the Carboniferous (Fig. 7). The depocentre may have been partly reactivated in the Triassic when the Hopen high shows signs of minor flexural uplift, or later when Cretaceous anticlinal development caused uplift and exposure of the island of Hopen. This late stage of reactivation is suggested by minor thickening of the latest Triassic-Jurassic (?) succession in places across the basin but cannot be substantiated.

The Olga basin is only partly covered by the available seismic data (Fig. 1A). It forms a shallow E-W-oriented depocentre that developed between large anticlines, the Storbanken and Sentralbanken highs (H-H', Fig. 5). Its location and orientation suggests that formation of the bounding anticlines triggered its development and the onlap pattern indicates an initiation of formation in the Early Cretaceous. The sag basin is underlain by strongly reflective segments, although it is difficult to discern if there is a Carboniferous depocentre beneath it. A deep, E-W-oriented, Carboniferous basin, the Ora basin (previously unnamed, here informally referred to after the polar vessel Ora, which sank in 1938, Figs. 2A, B, 5, G-G'), is also poorly resolved at depth, but can be traced with a higher degree of confidence. It lies northwest of 


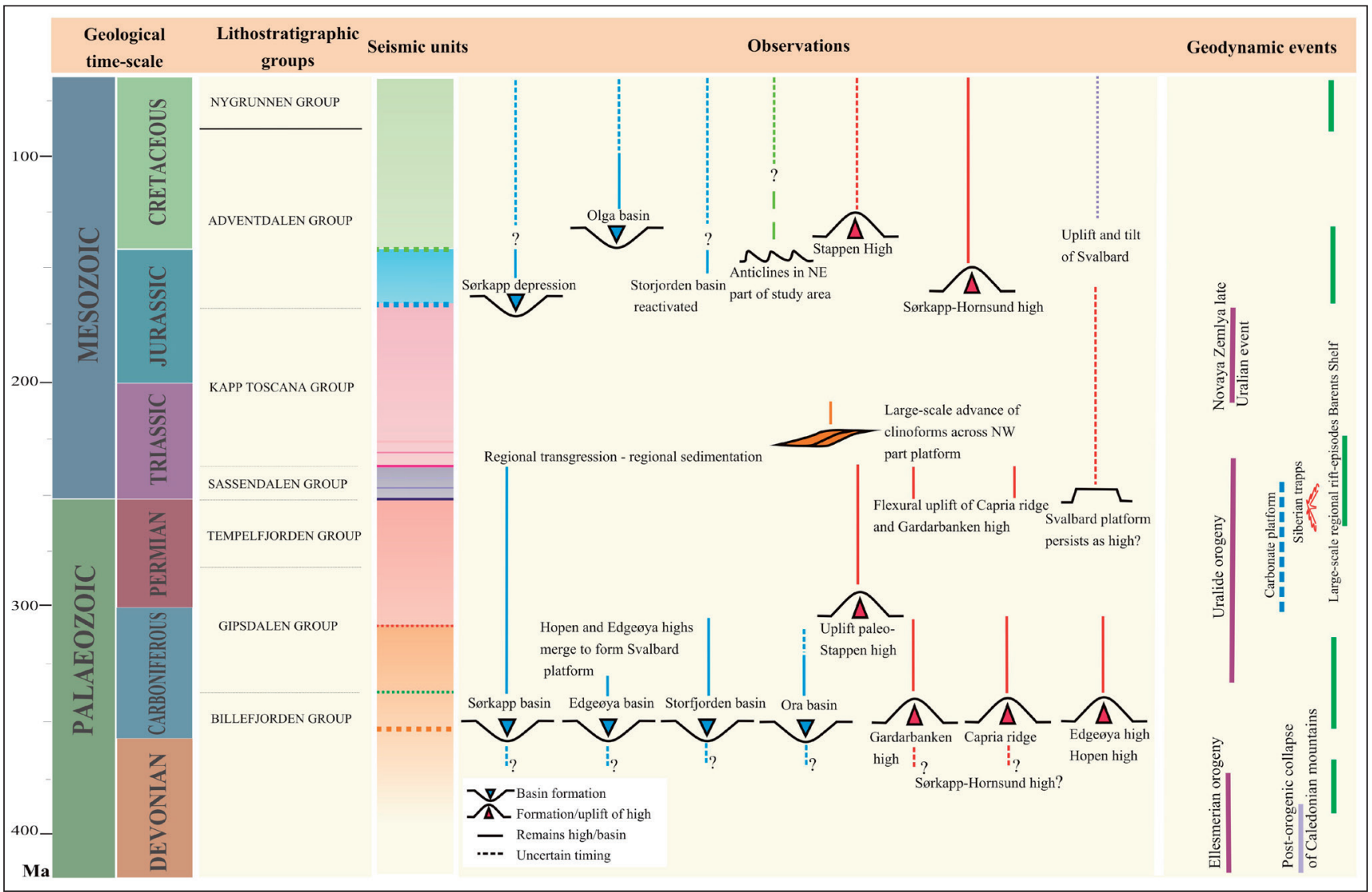

Figure 7. A summary figure showing the geological time scale with the names of the main lithostragraphic groups from the Barents Shelf and onshore Svalbard based on Dallmann (1999). The seismic units and the age of the main reflectors corresponding to the colours in Figs. 3-5 are shown, with stippled reflectors indicating a poorer age constraint. The observations from this study on the northwestern Barents Shelf are shown with symbols marking the approximate initiation and lines showing the duration of the structural influence, with stippled lines showing uncertainties. The last column indicates regional geodynamic events of the Barents Shelf and surrounding areas based on Otto \& Bailey (1995), Torsvik \& Andersen (2002), and Smelror et al. (2009).

the Olga basin and probably formed around the same time as many of the main structural elements (Figs. 6B, 7).

\section{Discussion}

The structural development on the northwestern Barents Shelf is considered to be controlled dominantly by the Caledonian and Uralian orogenies, although older orogens and sutures could also be influential, followed by the lengthy periodic rifting during onset of North Atlantic spreading (Fig. 7). The Silurian-Devonian Scandian phase of the Caledonian orogeny (McKerrow et al., 2000; Johansson et al., 2005; Gee et al., 2006) and later the Carboniferous-Triassic Uralian orogeny in the east (Rickard \& Belbin, 1980; Ziegler, 1988; Torsvik \& Andersen, 2002; Gee et al., 2006; Pease, 2011), are the two most recent significant collisional orogenic events to affect the northwestern Barents Shelf. The shelf underwent periodic rifting during several phases of extension which occurred in the Early-Mid Devonian, Mid Carboniferous to Early Permian, Late Permian to Early Triassic and Late Jurassic-Cretaceous (Fig. 7; Eldholm \& Thiede, 1980; Faleide et al., 1984; Doré, 1995; Gudlaugsson et al., 1998). The Billefjorden area, which has been extensively studied, provides an onshore analogue and may reflect many of the dominant phases that also affected parts of the northwestern Barents Shelf. The Billefjorden area underwent Devonian hyperextension which reverted to contraction in the latest Devonian (Braathen et al., 2010; Bergh et al., 2011). It was peneplaned to a lowland area during deposition of the Billefjorden Group in the Early Carboniferous, followed by extensive graben formation during Mid Carboniferous rifting which ended in the earliest Permian (Johannessen \& Steel, 1992; Braathen et al., 2011; Maher \& Braathen, 2011).

The Caledonian orogeny is considered to have been highly influential on the structural constellations observed across the Barents Shelf (Doré, 1992). The orogeny's main sutures are well established across large parts of northern Europe, but remain partly obscure on the Barents Shelf. The Barents Shelf was located in a complex, possibly sheared junction between the Ellesmerian fold belt and main Iapetus suture of 
the Caledonian orogeny (Doré, 1992). Recent highresolution aeromagnetic data suggest that the Caledonian nappes are arc-shaped and trend anticlockwise from NE-SW oriented to NW-SE towards the north and Svalbard (Gernigon et al., 2014). Our analysis of the main structural lineaments largely confirms this around the Stappen High, and suggests that to the north the trend follows a second more or less mirror-image curve, which reverts to a more dominant NE-SW orientation northeast of the Stappen High. This trend might reflect an influence from the Caledonian orogeny but could also be an inheritance from even older controlling lineaments.

\section{Carboniferous}

The earliest stages of development during the Devonian and Carboniferous are difficult to describe accurately other than it is apparent that many of the main structural elements developed at this time (Figs. 2A, 7). The Sørkapp basin formed the largest depocentre, and gravity modelling suggests it developed already in the Devonian (Grogan et al., 1999). Several other elongate, some narrow but quite deep, basins developed at the same time. Deep reflective segments beneath the Storfjorden basin attest to formation at an early stage followed by reactivation in the Late Mesozoic. The Edgeøya basin developed but became largely inactive following infill. Many highs still present today were formed and remained as highs throughout much of the Carboniferous, which is documented for example by the intra-Carboniferous planation surface apparent across the Capria ridge and a condensed main Carboniferous succession across the Gardarbanken high. Towards the end of the Carboniferous, most topography was blanketed and infill was relatively evenly spread across the area, although minor fault activity near the highs continued into the Late Carboniferous (Figs. 3, 4, 5) as witnessed by fault activity along the southern edge of the Hopen high (Fig. 5).

On Bjørnøya, which represents the subaerial exposure of the Stappen High, basement rocks crop out (Braathen et al., 1999b). The exposures on Bjørnøya reveal Devonian and Carboniferous, asymmetric, non-marine rift deposits that accumulated in a southwestward down-tilted halfgraben (Worsley et al., 2001) (E-E', Fig. 5). Resolution is very poor beneath the high and as it has undergone several stages of uplift the earliest stages of development are difficult to infer, as is an understanding of how the area around the paleo-Stappen high relates to the development around Bjørnøya. Deep reflectors suggest that there is a large fault and a half-graben of unknown age between the paleo-Stappen high and Bjørnøya (E-E, Fig. 5). This is supported by aeromagnetic data, which indicate that although the Stappen High forms a prominent regional high, the zone around Bjørnøya is a low-magnetic anomaly (Gernigon et al., 2014). Data from Bjørnøya suggest that the area was uplifted in the
Early Permian and peneplaned, and remained a positive feature until the Late Triassic (Worsley et al., 2001). This is similar to the development of the paleo-Stappen high, although as indicated by the results of this study the uplift of the paleo-Stappen high occurred earlier.

\section{Permian}

The latest Carboniferous saw a phase of uplift near the present continental margin. Large-scale down-to-west faulting caused footwall uplift and rotation of the paleoStappen high (Figs. 3C, 4C, 6A, 7), which was eroded and truncated and progressively onlapped from the east by Permian and Triassic deposits. The paleo-Stappen high could have formed a subaerial ridge which blocked much influx from eastern sources and served as a local source for sediment itself.

Across the remaining northwestern Barents shelf there is little evidence of large-scale movement. Overall, the latest Carboniferous through Permian appears to be tectonically quiescent, with most deposits uniformly thick across the area. However, towards the south, the paleo-Loppa High (also called the Selis ridge) (Glørstad-Clark et al., 2011) was initiated in the latest Carboniferous. It was subaerially exposed in the Mid to Late Permian and progressively onlapped along its eastern side during the Triassic (Bjørkesett, 2009; Glørstad-Clark et al., 2010; Blaich et al., 2012), indicating a development very similar to the paleo-Stappen high.

\section{Triassic}

The NE-SW-oriented Gardarbanken high, Capria ridge and Hopen high (Svalbard platform) show only limited structural influence on Permian deposition (F-F, G-G, Fig. 4). Meanwhile, Early Triassic deposition shows both onlap and truncation around the Gardarbanken high and Capria ridge, and thickness variation across faults on at least the southern side of the Hopen high (Svalbard platform), suggesting that these structures actively influenced accommodation at the time (Fig. 7). While the southwestern edge of the Capria ridge shows intermittent and complex Permo-Triassic deposition as it overlaps with the paleo-Stappen high, the northeastern side mostly displays evidence of Early Triassic uplift. This phase of reactivation appears to be dominantly flexural. The N-S-oriented paleo-Stappen high remained subaerial and was progressively onlapped during the Early Triassic; however, it is difficult to surmise to what extent it was reactivated in the Early Triassic. Transgression in the Ladinian meant that regional sedimentation ensued across all structural features at this stage (Fig. 7).

A progradational succession encompasses the Mid- to Late Triassic succession across the northern Barents 
Shelf (Riis et al., 2008; Glørstad-Clark et al., 2010; Høy \& Lundschien, 2011; Anell et al., 2014b) and hence is characterised by lateral variations in thickness (compare Line G-G' and Line H-H', Fig. 5). However, there is also an overall broad thinning of the whole Mesozoic succession towards the Svalbard platform, which can probably be attributed to initiation of uplift of the entire northern region (B-B', Fig. 4), which culminated in the Late Cretaceous (Steel \& Worsley, 1984). This meant that accommodation space towards the Svalbard platform was limited and that the prograding successions might have been deposited on a south- or southeast-sloping shallow platform.

\section{Mid Jurassic to recent}

The Mid Jurassic to recent is an extended time period to discuss, but the youngest preserved sedimentary successions on the northwestern Barents Shelf are generally Late Triassic or Jurassic, and in places Early Cretaceous. Therefore, while this time period probably embraces several stages of development, it is difficult to further discuss the specific timing of events.

The Late Jurassic-Early Cretaceous was a period associated with deep basin formation offshore Mid Norway, East Greenland and in the southwestern Barents Sea, a phase which preluded continental separation (Faleide et al., 2008). However, no major rift basins developed in the main study area. Instead, the observable depocentres are the Sørkapp depression and the Storfjorden and Olga basins (Figs. 6B, 7). The Sørkapp depression and the Storfjorden basin form two, small, rounded, asymmetric depocentres in which the base Cretaceous reflector is not pronounced, suggesting that the fill is dominantly of Mid to Late Jurassic age and characterised by onlapping geometries. The basins are asymmetric, steeper toward the west and shallow more gently toward the east, and the Stappen High and Sørkapp-Hornsund high form their respective western boundaries. The Capria ridge forms a crest between these two basins suggesting it influenced the location of formation of the two depocentres. The southeastern edge of the Sørkapp depression is bounded by an anticline (C-C', D-D', Fig. 4) which implies that its formation may be related to contractional deformation. The Central Spitsbergen Basin on Svalbard formed as a foreland basin during Early Tertiary folding and thrusting in the West Spitsbergen orogenic belt which developed by transpression as Greenland moved past Svalbard (Steel et al., 1985; Helland-Hansen, 1990; Nøttvedt et al., 1992b; Bergh et al., 1997; Braathen et al., 1999a; Faleide et al., 2008; Leever et al., 2011). It can be speculated whether the Storfjorden basin and Sørkapp depression could reflect responses to associated earlier contractional stresses. The Olga basin, meanwhile, formed between anticlines and is mainly a Cretaceous basin. The anticlines are oriented
NE-SW and reflect a phase of contraction which predominantly affected the eastern study area.

\section{Conclusions}

- The present structural configuration of the northwestern Barents Shelf is largely a reflection of the deep structural grain which has continued to influence sedimentation from the onset of rifting in the (latest Devonian?) Carboniferous. It is appreciable that several highs/upwarps and sags/downwarps have shifted their locus and timing of influence. This attests to shifting stress regimes impacting the shelf.

- The Stappen High, paleo-Stappen high and Capria ridge are separate features whose development have often been discussed as one. The Stappen High delineates a recent Cretaceous-Cenozoic high with maximum uplift and lateral extent south of Bjørnøya. The paleo-Stappen high is a N-S tilted, peneplaned, Late Carboniferous rift shoulder which eroded the Carboniferous deposits and is onlapped by Permian and Early Triassic sediments. The Capria ridge (informally named herein) outlines an old Palaeozoic NE-SW-oriented feature, reactivated in the Early Triassic, which at present forms a ridge between two chiefly Jurassic depocentres.

- The Edgeøya basin is a narrow rift basin which became largely inactive following infill in the Carboniferous, at which point the Hopen high and Edgeøya platform merged to form the Svalbard platform.

- The Storfjorden basin and Sørkapp depression were initiated around Mid Jurassic time. Both basins are asymmetrical with steeper faulted western limbs and gently climbing eastern limbs across bounding anticlinal features.

- The island of Hopen may owe its subaerial exposure to the development of a small local anticline, which probably formed together with a large number of NE-SW-oriented anticlinal structures which appear to have initiated in the Early Cretaceous. The Sentralbanken high is a prominent structure related to this event.

- The changes in orientation and influence attest to preferential reactivation of $\mathrm{N}$-S-oriented structures in the latest Carboniferous and post Mid Jurassic, and reactivation of old Carboniferous, NE-SW-oriented structures in the Early Triassic. Inversion along NESW lineaments, located predominantly in the northeastern part of the study area, developed dominantly from the Cretaceous onwards.

Acknowledgements. We are grateful for the insightful reviews provided by Stig Morten Knutsen and Laurent Gernigon. The study was undertaken as a part of the Trias North project which is financed by the Research Council of Norway and partners Tullow, Statoil Harstad, Lundin, Edison and Dea Norge AS. We kindly acknowledge the use of Petrel 2013, by Schlumberger, under academic license which was used for all seismic interpretations and map compilations. 


\section{Reference list}

Andersen, T.B. 1998: Extensional tectonics in the Caledonides of southern Norway, an overview. Tectonophysics 285, 333-351.

Andreassen, K., Laberg, J.S. \& Vorren, T.O. 2008: Seafloor geomorphology of the SW Barents Sea and its glaci-dynamic implications. Geomorphology 97, 157-177.

Anell, I., Braathen, A. \& Olaussen, S. 2014a: Regional constraints of the Sørkapp Basin: A Carboniferous relic or a Cretaceous depression? Marine and Petroleum Geology 54, 123-138.

Anell, I., Braathen, A. \& Olaussen, S. 2014b: The Triassic - Early Jurassic of the northern Barents Shelf: a regional understanding of the Longyearbyen CO2 reservoir. Norwegian Journal of geology 94, 83-98.

Anell, I., Midtkandal, I. \& Braathen, A. 2014c: Trajectory analysis and inferences on geometric relationships of an Early Triassic prograding clinoform succession on the northern Barents Shelf. Marine and Petroleum Geology 54, 167-179.

Antonsen, P., Elverhøi, A., Dypvik, H. \& Solheim, A. 1991: Shallow bedrock geology of the Olga basin area, nortwestern Barents Sea. American Association of Petroleum Geologists Bulletin 75, 11781194.

Barrère, C., Ebbing, J. \& Gernignon, L. 2009: Offshore prolongations of Caledonian structures and basement characterisation in the western Barents Sea from geophysical modelling. Tectonophysics 470, 71-88.

Bergh, S.G., Braathen, A. \& Andresen, A. 1997: Interaction of basement-involved and thin-skinned tectonism in the Tertiary foldand-thrust belt, central Spitsbergen, Svalbard. American Association of Petroleum Geologists Bulletin 81, 637-661.

Bergh, S.G., Maher, H.D.J. \& Braathen, A. 2011: Late Devonian transpressional tectonics in Spitsbergen, Svalbard and implications for basement uplift of the Sørkapp-Hornsund High. Journal of the Geological Society London 168, 441-456.

Bergsager, E. 1986: Future petroleum potential of the Barents Sea. In A.M. Spencer (ed.): Habitat of Hydrocarbons on the Norwegian Continental Shelf, Norwegian Petroleum Society, Graham and Trotham, London, pp. 339-354.

Berzin, R., Oncken, O., Knapp, J.H., Pérez-Estaún, A., Hismatulin, T., Yunusov, N. \& Lipilin, A. 1996: Orogenic Evolution of the Ural Mountains: Results from an Integrated Seismic Experiment. Science 274, 220-221.

Bjørkesett, S.S. 2009: Late Paleozoic-Triassic evolution of the paleoLoppa High, linked to tectonic events and depositional patterns. MSc Thesis, University of Oslo, Institutt for geofag, $93 \mathrm{pp}$.

Blaich, O.A., Faleide, J.I., Reider, M., Ersdal, G. \& Thyberg, B. 2012: Seismic velocities guiding geological interpretation in frontier arteas: the Stappen High area, SW Barents Sea. First Break 30, 73-77.

Braathen, A., Bergh, S.G. \& Maher Jr., H.D. 1999a: Application of a critical wedge taper model to the Tertiary transpressional fold-thrust belt on Spitsbergen. Geological Society of America Bulletin 111, 1468-1485.

Braathen, A., Maher, H.J., Haabet, T.E., Kristensen, S.E., Tørudbakken, B.O. \& Worsley, D. 1999b: Caledonian thrusting on Bjørnøya: implications for Palaeozoic and Mesozoic tectonism of the western Barents Shelf. Norsk Geologisk Tidskrift 79, 57-68.

Braathen, A., Osmundsen, P.T., Nordgulen, Ø., Roberts, D. \& Meyer, G. 2002: Orogen-parallel extension of the Caledonides in northern Central Norway: an overview. Norwegian Journal of Geology 82, 225-241.

Braathen, A., Osmundsen, P.T. \& Maher, H.J. 2010: Characteristics of a major Devonian extensional detachment on Spitsbergen - the Keiserhjelmen detachment. 29th Nordic Geological Winter Meeting, 29, 11-13 January, Oslo, Norway, p. 39.

Braathen, A., Bælum, K., Maher, H.J. \& Buckley, S.J. 2011: Growth of extenstional faults and folds during deposition of an evaporitedominated half-graben basin; the Carboniferous Billefjorden Trough, Svalbard. Norwegian Journal of geology 91, 137-160.
Bue, E.P. 2012: New U-Pb LA-ICPMS zircon provenance age data on Triassic sandstones (Vichekov, Vasilyev and Thegetthoff formations) from Franz Josef Land: preliminary results. In Nakrem, H.A. \& Haukdal, G.K. (eds.): Nordic Geological Winter Meeting 2013, p. 140.

Bue, E.P., Andresen, A., Andersen, T. \& Solbakken, R.T. 2010: Provenance of Mesozoic sediments from Spitsbergen, Wilhelmøya, Edgeøya and Hopen based on LA-MC-ICPMS U-Pb analyses of clastic zircons. In Brekke, H., Haukdal, G.K., Olesen, O. \& Thorsnes, T. (eds.): Arctic Days 2010, Tromsø 31st May-4th June, Geological Society of Norway.

Bælum, K. \& Braathen, A. 2012: Along-strike changes in fault array and rift basin geometry of the Carboniferous Billefjorden Trough, Svalbard, Norway. Tectonophysics 546, 38-55.

Dallmann, W.K. 1999: Introduction. In Dallmann, W.K. (ed.): Lithostratigraphic lexicon of Svalvard. Review and recommendations for nomenclature use, Upper Palaeozoic to Quaternary bedrock, Norsk Polarinstitutt, Tromsø, pp. 1-25.

Dallmann, W.K., Ohta, Y., Elvevold, S. \& Blomeier, D. 2002: Bedrock map of Svalbard and Jan Mayen. 1:750,000, with enlarged areas 1:250,000. Norsk Polarinstitutt Temakart No. 33.

Dengo, C.A. \& Røssland, K.G. 1992: Extensional tectonic history of the western Barents Sea. In Larsen, R., Brekke, H., Larsen, B. \& Talleraas, E. (eds.): Structural and tectonic modelling and its application to petroleum geology, Norwegian Petroleum Society Special Publication 1, Elsevier, Amsterdam, pp. 91-107.

Doré, A.G. 1992: Synoptic palaeogeography of the Northeast Atlantic Seaway: late Permian to Triassic. In Parnell, J. (ed.): Basins on the Atlantic Seaboard: Petroleum Geology, Sedimentology and Basin Evolution, Geological society of London special publications 62, pp. 421-446.

Doré, A.G. 1995: Barents Sea Geology, Petroleum Resources and Commerical Potential. Arctic 48, 207-221.

Doré, A.G., Lundin, E.R., Jensen, L.N., Birkeland, Ø., Eliassen, P.E. \& Fichler, C. 1999: Principal tectonic events in the evolution of the northwest European Atlantic margins. In Fleet, A.J. \& Boldy, S.A.R. (eds.): Petroleum geology of Northwest Europe: Proceedings of the $5^{\text {th }}$ conference, Geological society London, pp. 41-61.

Eldholm, O. \& Thiede, J. 1980: Cenozoic continental separation beween Europe and Greenland. Palaeoceanography Palaeoclimatology Palaeoecology 30, 243-259.

Elverhøi, A., Antonsen, P., Flood, S.B., Solheim, A. \& Vullstad, A.A. 1988: Western Barents Sea - Shallow bedrock geology. Norsk Polarinstitutts Skrifter 179, 1-32.

Faleide, J.I. \& Gudlaugsson, S.T. 1981: Geology of the western Barents Sea - a Regional study based on marine and geophysical data. Cand. Real. Thesis, University of Oslo, 160 pp.

Faleide, J.I., Gudlaugsson, S.T. \& Jacquart, G. 1984: Evolution of the western Barents Sea. Marine and Petroleum Geology 1, 123-128.

Faleide, J.I., Gudlaugsson, S.T., Eldholm, O., Myhre, A.M. \& Jackson, H.R. 1991: Deep seismic transects across the sheared western Barents Sea-Svalbard continental margin. Tectonophysics 189, 73-89.

Faleide, J.I., Vågnes, E. \& Gudlaugsson, S.T. 1993: Late Mesozoic-Cenozoic evolution of the southwestern Barents Sea in a regional riftshear tectonic setting. Marine and Petroleum Geology 10, 186-214.

Faleide, J.I., Tsikalas, F., Breivik, A.J., Mjelde, R., Ritzmann, O., Engen, $\varnothing$., Wilson, J. \& Eldholm, O. 2008: Structure and evolution of the continental margin off Norway and the Barents Sea. Episodes 31, 82-91.

Faleide, J.I., Bjørlykke, K. \& Gabrielsen, R.H. 2010: Geology of the Norwegian Continental Shelf. In Bjørlykke, K. (ed.): Petroleum Geoscience, Springer-Verlag, Berlin, pp. 603-637.

Falk-Petersen, S., Hop, H., Budgell, W.P., Hegseth, E.N., Korsnes, R., Løyning, T.B., Ørbæk, J.B., Kawamura, T. \& Shirasawa, K. 2000: Physical and ecological processes in the marginal ice zone of the northern Barents Sea during the summer melt period. Journal of Marine Systems 27, 131-159. 
Gabrielsen, R. 1984: Long-lived fault-zones and their development of the south-western Barents Sea. Journal of Geological Society London $141,651-662$.

Gabrielsen, R.H., Faerseth, R., Hamar, G. \& Rønnevik, H. 1984: Nomenclature of the main structural features on the Norwegian Continental Shelf north of the 62nd parallel. In Spencer A.M. et al. (eds.): Petroleum geology of the North European Margin, Springer, Netherlands, pp. 41-60.

Gabrielsen, R., Færseth, R., Jensen, L.N., Kalheim, J.E. \& Riis, F. 1990: Structural elements of the Norwegian Continental Shelf, Part 1: The Barents Sea Region. Norwegian Petroleum Directorate Bulletin $6,1-47$.

Gac, S., Huismans, R.S., Podladchikov, Y.Y. \& Faleide, J.I. 2012: On the origin of the ultradeep East Barents Sea basin. Journal of Geophysical Research 117, 1-16.

Gee, D. 1975: A tectonic model for the central part of the Scandiavian Caledonides. American Journal of Science 275-A, 468-515.

Gee, D.G. \& Teben'kov, A.M. 2004: Svalbard: a fragment of the Laurentian margin. In Gee, D.G. \& Pease, V. (eds.): The Neoproterozoic Timanide orogen of Eastern Baltica, The Geological Society of London Memoirs 30, pp. 191-206.

Gee, D.G., Bogolepova, O.K. \& Lorenz, H. 2006: The Timanide, Caledonide and Uralide orogens in the Eurasian high arctic, and relationships to the Palaeo-contienents Laurentia, Baltica and Sibera. In Gee, D.G. \& Stephernson, R.A. (eds.): European Lithosphere Dynamics, The Geological Society of London Memoirs 32, pp. 507-520.

Gernigon, L. \& Brönner, M. 2012: Late Palaeozoic architecture and evolution of the southwestern Barents Sea: insights from a new generation of aeromagnetic data. Journal of the Geological Society London 169, 449-459.

Gernigon, L., Brönner, M., Roberts, D., Olesen, O., Nasuti, A. \& Yamasaki, T. 2014: Crustal and basin evolution of the southwestern Barents Sea: From Caledonian orogeny to continental breakup. Tectonics, 33, 347-373.

Glørstad-Clark, E., Faleide, J.I., Lundschien, B.A. \& Nystuen, J.P. 2010: Triassic seismic sequence stratigraphy and paleogeography of the western Barents Sea area. Marine and Petroleum Geology 27, 14481475 .

Glørstad-Clark, E., Birkeland, E.P., Nystuen, J.P., Faleide, J.I. \& Midtkandal, I. 2011: Triassic platform-margin deltas in the western Barents Sea. Marine and Petroleum Geology 28, 1294-1314.

Grogan, P., Østvedt-Ghazi, A.-M., Larssen, G.B., Fotland, B., Nyberg, K., Dahlgren, S. \& Eidvin, T. 1999: Structural elements and petroleum geology of the Norwegian sector of the northern Barents Sea. In Fleet. A.J. \& Boldy, S.A.R. (eds.): Petroleum Geology of Northwest Europe: Proceedings of the 5th Conference, Geological Society London, London, pp. 247-259.

Gudlaugsson, S.T., Faleide, J.I., Johansen, S.E. \& Breivik, A.J. 1998: Late Paleozoic structural development of the south-western Barents Sea. Marine and Petroleum Geology 15, 73-102.

Halland, E.K., Bjørnestad, A., Gjeldvik, I.T., Bjørheim, M., Magnus, C., Meling, I.M., Mujezinovic, J., Riis, F., Rød, R.S., Pham, V.T.H. \& Tappel, I. 2014: The Barents Sea. In Halland, E.K., Johansen, W.T. \& Riis, F. (eds.): CO2 samleatlas for Norsk kontinentalsokkel, Norwegian Petroleum Directorate, Stavanger, pp. 107-145.

Helland-Hansen, W. 1990: Sedimentation in Paleogene foreland basin, Spitsbergen. American Association of Petroleum Geologists Bulletin 74, 260-272.

Henriksen, E., Ryseth, A.E., Larssen, G.B., Heide, T., Rønning, K., Sollid, K. \& Stoupakova, A.V. 2011: Tectonostratigraphy of the greater Barents Sea: implications for petroleum systems. In Spencer, A.M., Embry, A.F., Gautier, D.L., Stoupakova, A.V. \& Sørensen, K. (eds.): Arctic Petroleum Potential, Geological Society of London Memoirs 35, pp. 163-195.

Higgins, A., Soper, N. \& Leslie, A. 2000: The Ellesmerian and Caledonian orogenic belts of Greenland. Polarforschung 68, 141-151.
Høy, T. \& Lundschien, B.A. 2011: Triassic deltaic sequences in the northern Barents Sea. In Spencer, A.M., Embry, A.F., Gautier, D.L., Stoupakova, A.V. \& Sørensen, K. (eds.): Arctic Petroleum Potential, Geological Society of London Memoirs 35, pp. 249-260.

Johannessen, E.P. \& Steel, R.J. 1992: Mid-Carboniferous extension and rift-infill sequences in the Billefjorden Trough, Svalbard. Norsk Geologisk Tidsskrift 72, 35-48.

Johansson, Å., Gee, D.G., Larionov, A.N., Ohta, Y. \& Tebenkov, A.M. 2005: Grenvillian and Caledonian evolution of eastern Svalbard-a tale of two orogenies. Terra Nova 17, 317-325.

Labrousse, L., Elvevold, S., Lepvrier, C. \& Agard, P. 2008: Structural analysis of high囚pressure metamorphic rocks of Svalbard: Reconstructing the early stages of the Caledonian orogeny. Tectonics 27, 1-22.

Leever, K.A., Gabrielsen, R.H., Faleide, J.I. \& Braathen, A. 2011: A transpressional origin for the West Spitsbergen fold-and-thrust belt: Insight from analog modelling. Tectonics 30,1-24.

Maher, H.J. \& Braathen, A. 2011: Løvehovden fault and Billefjorden rift basin segmentation and development, Spitsbergen, Norway. Geological Magazine 148, 154-170.

McKerrow, W.S., Mac Niocaill, C. \& Dewey, J.F. 2000: The Caledonian Orogeny redefined. Journal of the Geological Society London 157, 1149-1154.

Mørk, A., Knarud, R. \& Worsley, D. 1982: Depositional and diagenetic environments of the Triassic and lower Jurassic succession of Svalbard. Arctic Geology and Geophysics: Proceedings of the Third International Symposium on Arctic Geology, Canadian Society of Petroleum Geology Memoir 8, pp. 371-398.

Nøttvedt, A., Cecchi, M., Gjelberg, J.C., Kristensen, S.E., Lønøy, A., Rasmussen, A., Rasmussen, E., Skott, P.H. \& van Veen, P.M. 1992a: Svalbard-Barents Sea correlation: a short review. In Vorren, T.O., Bergsager, E., Dahl-Stamnes, Ø.A., Holter, E., Johansen, B., Lie, E. \& Lund, T.B. (eds): Arctic Geology and Petroleum Potential, Norwegian Petroleum Society Special Publications 2, Elsevier, Amsterdam, pp. 363-375.

Nøttvedt, A., Livbjerg, F., Modbøe, P.S. \& Rasmussen, E. 1992b: Hydrocarbon potential of the Central Spitsbergen Basin. In Vorren, T.O., Bergsager, E., Dahl-Stamnes, Ø.A., Holter, E., Johansen, B., Lie, E. \& Lund, T.B. (eds.): Arctic Geology and Petroleum Potential, Norwegian Petroleum Society Special Publications 2, Elsevier, Amsterdam, pp. 333-361.

Otto, S.C. \& Bailey, R.J. 1995: Tectonic evolution of the northern Ural Orogen. Journal of the Geological Society London 152, 903-906.

Pease, V. 2011: Eurasian orogens and Arctic tectonics; an overview. In Spencer, A.M., Embry, A.F., Gautier, D.L., Stoupakova, A.V. \& Sorensen, K. (eds.): Arctic Petroleum Geology, Geological Society of London Memoirs 35, pp. 311-324.

Rickard, M.J. \& Belbin, L. 1980: A new continental assembly for Pangaea. Tectonophysics 63, 1-12.

Riis, F., Vollset, J. \& Sand, M. 1986: Tectonic development of the western margin of the Barents Sea and adjacent areas. American Association of Petroleum Geologists Memoirs 40, 661-675.

Riis, F., Lundschien, B.A., Høy, T., Mørk, A. \& Mørk, M.-B.E. 2008: Evolution of the Triassic shelf in the northern Barents Sea region. Polar Research 27,318-338.

Ritzmann, O. \& Faleide, J.I. 2009: The crust and mantle lithosphere in the Barents Sea/Kara region. Tectonophysics 470, 89-104.

Roberts, D. \& Siedlecka, A. 2002: Timanian orogenic deformation along the northeastern margin of Baltica, Northwest Russia and Northeast Norway, and Avalonian-Cadomian connections.Tectonophysics 352, 169-184.

Rønnevik, H. \& Jacobsen, H.P. 1984: Structural highs and basins in the western Barents Sea. In Spencer, A.M. et al. (eds.): Petroleum Geology of the North European Margin, Springer, Netherlands, pp. 19-32.

Rønnevik, H., Beskow, B. \& Jacobsen, H.P. 1982: Structural and stratigraphic evolution of the Barents Sea. Offshore Northern Seas - The 
geological framework and hydrocarbon potential of basins in the northern seas, 24-27 August, Stavanger, Norway, pp. 431-440

Siedlecka, A., Roberts, D., Nystuen, J.P. \& Olovyanishnikov, V.G. 2004: Northeastern and northwestern margins of Baltica in Neoproterozoic time: evidence from the Timanian and Caledonian Orogens. In Gee, D.G. \& Pease, V. (eds.): The Neoproterozoic Timanide Orogen of Eastern Baltica, Geological Society of London Memoirs 30, pp. 169-190.

Sigmond, E.M.O. 1992: Bedrock map, Norway and adjacent ocean areas, scale 1:3 million, Norges Geologiske Undersøkelse.

Skilbrei, J.R. 1991: Interpretation of depth to the magnetic basement in the northern Barents Sea (south of Svalbard). Tectonophysics 200, 127-141.

Smelror, M., Petrov, O.V., Larssen, G.B. \& Werner, S.C. 2009: Geological History of the Barents Sea - Atlas. Geological Survey of Norway, Trondheim, $135 \mathrm{pp}$.

Solheim, A. \& Elverhøi, A. 1993: Gas-related sea floor craters in the Barents Sea. Geo-Marine Letters 13, 235-243.

Soper, N.J. \& Higgins, A.K. 1990: Models for the Ellesmerian mountain front in North Greenland: a basin margin inverted by basement uplift. Journal of Structural Geology 12, 83-97.

Steel, R.J. \& Worsley, D. 1984: Svalbard's post-Caledonian strata - an atlas of sedimentational patterns and palaeogeographic evolution. In Spencer, A.M. et al. (eds.): Petroleum Geology of the North European Margin, Springer, Netherlands, pp. 109-135.

Steel, R.J., Gjelberg, J., Helland-Hansen, W., Kleinspehn, K.L., Nøttvedt, A. \& Larsen, M.R. 1985: The Tertiary strike-slip basins and orogenic belt of Spitsbergen. In Biddle, K. \& Christie-Blick, N. (eds.): Strike-slip deformation, basin formation and sedimentation, Society for Sedimentary Geology Special Publications 37, pp. 339-359.

Torsvik, T.H. \& Andersen, T.B. 2002: The Taimyr fold belt, Arctic Siberia: timing of prefold remagnetisation and regional tectonics. Tectonophysics 352, 335-348.

Witt-Nilsson, P., Gee, D.G. \& Hellman, F.J. 1998: Tectonostratigraphy of the Caledonian Atomfjella Antiform of northern Ny Friesland, Svalbard. Norsk Geologisk Tidsskrift 78, 67-80.

Wood, R., Edrich, S. \& Hutchison, I. 1989: Influence of North Atlantic Tectonics on the Large-Scale Uplift of the Stappen High and Loppa High, Western Barents Shelf: Chapter 36: North Sea and Barents Shelf. In Tankard, A.J. \& Blackwell, H.R. (eds.): Extensional Tectonics and Stratigraphy of the North Atlantic Margins, American Association of Petroleum Geologists Memoirs 46, pp. 559-566.

Worsley, D. 2008: The post-Caledonian development of Svalbard and the western Barents Sea. Polar Research 27, 298-317.

Worsley, D., Agdestein, T., Gjelberg, J.G., Kirkemo, K., Mørk, A., Nilsson, I., Olaussen, S., Steel, R.J. \& Stemmerik, L. 2001: The geological evolution of Bjørnøya Arctic Norway: implications for the Barents Shelf. Norwegian Journal Geology 81, 195-234.

Ziegler, P.A. 1988: Evolution of the Arctic-North Atlantic and the Western Tethys. American Association of Petroleum Geologists Memoir 43, 164-196. 